DOI: https://doi.org/10.24127/ajpm.v10i2.3458

\title{
KESALAHAN MAHASISWA SEMESTER PERTAMA DALAM MENYELESAIKAN MASALAH FUNGSI TRIGONOMETRI SUDUT TIDAK LANCIP
}

\author{
Yayan Eryk Setiawan ${ }^{1 *}$ \\ ${ }^{1 *}$ Universitas Islam Malang, Malang, Indonesia \\ * Corresponding author. Dusun Krajan 2 RT.03 RW.05 Desa Boreng Kecamatan Lumajang, kode pos 67316, \\ Kabupaten Lumajang, Indonesia. \\ E-mail: $\quad$ yayaneryksetiawan@unisma.ac.id ${ }^{\left.{ }^{*}\right)}$
}

Received 06 January 2021; Received in revised form 11 June 2021; Accepted 28 June 2021

\begin{abstract}
Abstrak
Hasil penelitian pendahuluan menunjukkan bahwa mahasiswa semester pertama masih banyak mengalami kesalahan dalam menyelesaikan masalah fungsi trigonometri sudut tidak lancip. Kesalahankesalahan ini perlu diteliti lebih lanjut. Oleh karena itu, penelitian ini bertujuan untuk mendeskripsikan kesalahan mahasiswa semester pertama dalam menyelesaikan masalah fungsi trigonometri sudut tidak lancip beserta faktor-faktor penyebabnya. Jenis penelitian ini adalah penelitian deskriptif kualitatif dengan pendekatan studi kasus terhadap mahasiswa semester pertama yang mengalami kesalahan dalam menyelesaikan masalah fungsi trigonometri sudut tidak lancip. Subjek penelitian ini terdiri dari 7 mahasiswa program studi pendidikan matematika di salah satu perguruan tinggi di kota Malang. Data yang dikumpulkan dalam penelitian ini yaitu hasil pekerjaan subjek dan transkrip hasil wawancara dengan subjek. Analisis hasil pekerjaan subjek dilakukan secara deskriptif yang bertujuan untuk mengategorikan kesalahan subjek. Sedangkan analisis transkrip hasil wawancara dilakukan dengan pengkodean yang bertujuan untuk mengetahui faktor-faktor penyebab kesalahan subjek. Hasil penelitian menunjukkan bahwa dari 38 mahasiswa yang mengalami kesalahan diperoleh: 53\% mengalami kesalahan konsep, $31 \%$ mengalami kesalahan hitung, dan 16\% mengalami kesalahan fakta. Kesalahan konsep disebabkan karena kesalahpahaman terhadap konsep sudut referensi dan tidak memperhatikan kuadran. Kesalahan hitung disebabkan kesalahpahaman terhadap operasi hitung dan kurang teliti. Kesalahan fakta disebabkan kurang memperhatikan informasi dalam soal.
\end{abstract}

Kata kunci: Kesalahan fakta; kesalahan hitung; kesalahan konsep; sudut tidak lancip; trigonometri.

\begin{abstract}
The results of preliminary research show that the first semester students still experience many errors in solving the problem of non-acute angle trigonometric functions. These errors need further investigation. Therefore, this study aims to describe the errors of the first semester students in solving the problem of non-acute angle trigonometric functions and their causes. This type of research is a qualitative descriptive study with a case study approach to first semester students who experience errors in solving the problem of non-acute angle trigonometric functions. The subjects of this research consisted of 7 students of the mathematics education study program at one of the universities in Malang. The data collected in this study are the results of the subject's work and transcripts of interviews with the subject. Analysis of the results of the subject's work is done descriptively which aims to categorize the subject's errors. While the transcript analysis of the interview results was carried out by coding which aims to determine the factors causing the subject's errors. The results showed that of the 38 students who had errors obtained: $53 \%$ had misconceptions, $31 \%$ had miscalculations, and $16 \%$ had factual errors. Misconceptions are caused due to misunderstanding of the concept of the reference angle and not paying attention to quadrants. Miscalculations are caused by a misunderstanding of arithmetic operations and less thoroughness. Factual errors are caused by not paying attention to the information in the questions.
\end{abstract}

Keywords: Factual errors; miscalculations; misconceptions; non-acute angles; trigonometry. 
DOI: https://doi.org/10.24127/ajpm.v10i2.3458

\section{PENDAHULUAN}

Salah satu mata kuliah yang harus ditempuh oleh mahasiswa program studi pendidikan matematika adalah Trigonometri. Trigonometri didefinisikan sebagai cabang ilmu matematika yang membahas mengenai segitiga (Downing, 2009) dan secara khusus membahas mengenai fungsifungsi trigonometri (Lial et al., 2016). Pentingnya mata kuliah trigonometri untuk diberikan kepada mahasiswa program studi pendidikan matematika dikarenakan materi trigonometri dibelajarkan pada jenjang Sekolah Menengah Atas (SMA). Oleh karena itu sebagai mahasiswa calon guru, sudah seharusnya menguasai konsep-konsep trigonometri sebelum mereka membelajarkannya pada siswa SMA. Selain itu, materi pada mata kuliah trigonometri ini banyak memuat konsep dan banyak diaplikasikan dalam berbagai bidang (Nabie et al., 2018; Nejad, 2016). Mata kuliah trigonometri ini juga merupakan prasyarat untuk mata kuliah kalkulus, analisis vektor, dan persamaan diferensial. Jadi dapat dikatakan bahwa mata kuliah trigonometri ini penting untuk dipahami oleh mahasiswa calon guru.

Salah satu materi yang dibahas dalam mata kuliah trigonometri adalah nilai fungsi trigonometri sudut tidak lancip. Sudut tidak lancip dalam penelitian ini didefinisikan sebagai sudut yang besarnya lebih dari $90^{\circ}$ dan kurang dari $360^{\circ}$ (Lial et al., 2016). Contoh sudut tidak lancip adalah $120^{\circ}$, $135^{\circ} 240^{\circ}$, dan sebagainya. Ini artinya fungsi trigonometri sudut tidak lancip adalah fungsi trigonometri yang memuat sudut lebih dari $90^{\circ}$ dan kurang dari $360^{\circ}$. Misalnya $\sin 120^{\circ}$, $\cos 135^{\circ}, \tan 240^{\circ}$, dan sebagainya.

Cara untuk menentukan nilai fungsi trigonometri sudut tidak lancip ini dilakukan dengan tiga langkah. Misalnya kita akan mencari nilai dari $\sin 120^{\circ}$. Langkah pertama adalah mencari sudut referensi, dimana sudut referensi didefinisikan sebagai sudut lancip yang bukan sudut kuadran dalam posisi standar (Downing, 2009; Lial et al., 2016). Penentuan sudut referensi ini dilakukan dengan memperhatikan letak kuadran dari sudut tidak lancip. Misalkan sudut referensi dari sudut $\theta$ adalah $\theta^{\prime}$. Jika $\theta$ terletak di kuadran I, maka sudut referensinya adalah $\theta^{\prime}=\theta$. Jika $\theta$ terletak di kuadran II, maka sudut referensinya adalah $\theta^{\prime}=180^{\circ}-\theta$. Jika $\theta$ terletak di kuadran III, maka sudut referensinya adalah $\theta^{\prime}=\theta-$ $180^{\circ}$. Jika $\theta$ terletak di kuadran IV, maka sudut referensinya adalah $\theta^{\prime}=360^{\circ}-\theta$. Karena sudut $120^{\circ}$ terletak di kuadran II, maka sudut referensinya adalah $180^{\circ}-120^{\circ}=$ $60^{\circ}$. Langkah kedua adalah menentukan tanda dari fungsi yang ditanyakan. Karena $\sin 120^{\circ}$ terletak di kuadran II, maka bertanda positif. Langkah ketiga adalah menentukan nilai fungsi trigonometri sudut tidak lancip yang ditanyakan, yaitu $\sin 120^{\circ}=\sin 60^{\circ}=$ $\frac{1}{2} \sqrt{3}$. Jadi diperoleh nilai dari $\sin 120^{\circ}=\frac{1}{2} \sqrt{3}$.

Materi nilai fungsi trigonometri sudut tidak lancip ini penting untuk dikuasai oleh mahasiswa calon guru. Hal ini dikarenakan materi ini dibelajarkan pada jenjang SMA. Akan tetapi, hasil penelitian pendahuluan menunjukkan bahwa dari 82 mahasiswa semester pertama program studi pendidikan matematika menunjukan bahwa terdapat 44 mahasiswa menjawab benar dan 38 mahasiswa menjawab salah dalam menentukan nilai fungsi trigonometri sudut tidak lancip. Ini artinya terdapat $46 \%$ mahasiswa mengalami kesalahan dalam 
menentukan nilai fungsi trigonometri sudut tidak lancip. Kesalahan-kesalahan yang dilakukan oleh mahasiswa ini penting untuk dianalisis lebih lanjut. Hal ini dikarenakan dengan ditemukannya kesalahpahaman mahasiswa dan faktor-faktor penyebabnya, maka mahasiswa mendapatkan penjelasan dari kesalahan yang dilakukan (Herholdt \& Sapire, 2014), dapat mengatasi kesulitannya dalam memahami matematika (Marpa, 2019), dapat memperbaiki kesalahpahamannya (Setiawan, 2020b, 2020d, 2021a), mendapatkan gambaran mengenai kelemahannya dalam menyelesaikan masalah (Siregar, 2019), dan dapat meminimalisir kesalahan yang dilakukan dalam menyelesaikan masalah matematika (Murtiyasa \& Wulandari, 2020). Selain itu, hasil penelitian yang berupa kesalahpahaman siswa atau mahasiswa dapat digunakan oleh guru atau dosen untuk memperbaiki pembelajarannya di kelas dengan menekankan pada hal-hal yang menunjukkan kesalahan saat menyelesaikan masalah matematika (Setiawan, 2020b, 2020c, 2020a), selain itu guru atau dosen juga dapat meningkatkan keterampilan komunika-sinya dalam membelajarkan matematika (Guce, 2017). Oleh karena itu penting untuk melakukan analisis kesalahan yang dilakukan oleh mahasiswa dalam menyelesaikan masalah fungsi trigonometri sudut tidak lancip.

Pentingnya analisis kesalahan ini menyebabkan beberapa penelitian telah dilakukan untuk menganalisis kesalahan mahasiswa dalam menyelesaikan masalah trigonometri, yaitu (Hidayat \& Aripin, 2020; Imelda, 2018; Jaelani, 2017; Nabie et al., 2018; Setiawan, 2021a, 2021b; Tuna, 2013). Akan tetapi penelitian yang telah dilakukan sebelumnya tidak membahas mengenai kesalahan mahasiswa dalam menyelesaikan masalah fungsi trigonometri sudut tidak lancip. Oleh karena itu masih dibutuhkan penelitian tentang analisis kesalahan mahasiswa dalam menyelesaikan masalah nilai fungsi trigonometri sudut tidak lancip.

Berbeda dengan penelitian yang telah dilakukan sebelumnya (Hidayat \& Aripin, 2020; Imelda, 2018; Jaelani, 2017; Nabie et al., 2018; Setiawan, 2021a, 2021b; Tuna, 2013), penelitian ini bertujuan untuk mendeskripsikan kesalahan-kesalahan mahasiswa dalam menyelesaikan masalah nilai fungsi trigonometri sudut tidak lancip. Hasil penelitian ini memiliki manfaat secara teoritis yang berupa teori kesalahan dalam menyelesaikan masalah fungsi trigonometri sudut tidak lancip. Hasil penelitian ini juga memiliki manfaat praktis, yaitu pembelajaran untuk mengurangi kesalahan-kesalahan mahasiswa dalam memahami materi maupun menyelesaikan masalah nilai fungsi trigonometri sudut tidak lancip.

\section{METODE PENELITIAN}

Metode penelitian ini menggunakan penelitian deskriptif kualitatif dengan pendekatan studi kasus terhadap 7 mahasiswa program studi pendidikan matematika di Universitas Islam Malang yang menjadi subjek penelitian ini. proses pemilihan subjek dilakukan dengan tiga langkah. Langkah pertama meminta mahasiswa untuk menyelesaikan soal Ujian Tengah Semester (UTS) yang salah satu soalnya adalah nilai fungsi trigonometri sudut tidak lancip (lihat Gambar 1). Langkah kedua adalah mengoreksi jawaban berdasarkan jawaban benar dan jawaban salah, sehingga diperoleh 44 mahasiswa menjawab benar dan 38 mahasiswa menjawab salah dalam menyelesaikan masalah fungsi trigonometri sudut tidak 
lancip. Langkah ketiga adalah menglasifikasikan kesalahan mahasiswa berdasarkan kerangka kerja klasifikasi kesalahan (lihat Tabel 1). Dari hasil klasifikasi kesalahan (lihat Tabel 2) akan diambil 3 subjek untuk kesalahan konsep, 2 subjek untuk kesalahan hitung, dan 2 subjek untuk kesalahan fakta. Pengambilan subjek yang berbeda ini didasarkan pada analisis perbandingan dan mahasiswa yang mengalami kesalahan konsep lebih banyak daripada kesalahan hitung dan kesalahan fakta. Sehingga diperoleh subjek sebanyak 7 mahasiswa.

Sesuai dengan metode penelitian ini, maka data yang dikumpulkan dalam penelitian ini terdiri dari hasil pekerjaan subjek dan transkrip hasil wawancara. Prosedur pengumpulan hasil pekerjaan subjek dilakukan sesuai prosedur pemilihan subjek, sedangkan prosedur pengumpulan transkrip hasil wawancara dilakukan dalam dua langkah. Langkah pertama adalah melakukan wawancara dengan subjek penelitian melalui whatsapp. Langkah kedua adalah mentranskrip hasil wawancara kata demi kata, sehingga diperoleh transkrip hasil wawancara dengan subjek secara lengkap.

Sesuai dengan data yang dikumpulkan dalam penelitian ini, maka instrumen penelitian ini terdiri dari masalah fungsi trigonometri sudut tidak lancip (lihat Gambar 1) dan pedoman wawancara. Dari Gambar 1 dapat dilihat bahwa instrumen penelitian ini dapat diselesaikan dengan menerapkan konsep sudut referensi, tanda dari nilai fungsi trigonometri di masing-masing letak kuadran, dan nilai fungsi trigonometri sudut istimewa. Ini artinya jika mahasiswa tidak memahami konsep sudut refrensi, tanda dari nilai fungsi trigonometri di masing-masing kuadran, dan nilai fungsi trigonometri sudut istimewa, maka mahasiswa akan mengalami kesalahan konsep. Kesalahan konsep adalah kesalahpahaman dalam memahami suatu konsep (Setiawan, 2020c).

Tentukan nilai dari fungsi trigonometri berikut
(a) $3 \sin ^{2} 150^{\circ}-2 \tan ^{2} 120^{\circ}-$ $\cos ^{2} 180^{\circ}-\cot ^{2} 135^{\circ}+$ $\sec ^{2} 120^{\circ}=\cdots$
(b) $\csc ^{2} 135^{0}+\sec ^{2} 150^{\circ}$ $\cot ^{2} 210^{0}=\cdots$
(c) $3 \sin ^{2} 120^{\circ}-2 \cos ^{2} 120^{\circ}-$ $\cos ^{2} 180^{\circ}-\csc ^{2} 135^{\circ}+$ $\sec ^{2} 120^{\circ}=\cdots$
(d) $3 \sin ^{2} 150^{\circ}-2 \tan ^{2} 45^{\circ}-$ $\sec ^{2} 180^{\circ}-\csc ^{2} 135^{\circ}+$ $\cot ^{2} 90^{\circ}=\cdots$

Gambar 1. Instrumen penelitian

Pada soal juga melibatkan operasi hitung. Jika mahasiswa mengalami kesalahan dalam menentukan hasil operasi hitung, maka mahasiswa mengalami kesalahan hitung. Selanjutnya jika mahasiswa mengalami kesalahan dalam mengidentifikasi informasi yang ada dalam soal, maka mahasiswa mengalami kesalahan fakta. Kesalahan fakta dalam penelitian ini didefinisikan sebagai kesalahan dalam mengidentifikasi informasi yang ada dalam soal atau kesalahan memberi makna simbol matematika (Setiawan, 2020c). Jadi secara umum dapat dikatakan bahwa instrumen penelitian ini valid digunakan untuk mengidentifikasi kesalahan mahasiswa dalam menyelesaikan masalah fungsi trigonometri sudut tidak lancip berdasarkan kesalahan konsep, kesalahan hitung, dan kesalahan fakta.

Analisis data dari hasil pekerjaan mahasiswa dilakukan dengan menglasifikasikan berdasarkan kesalahan konsep, kesalahan hitung, dan kesalahan fakta (lihat Tabel 1). 
DOI: https://doi.org/10.24127/ajpm.v10i2.3458

Tabel 1. Kerangka kerja klasifikasi kesalahan mahasiswa

\begin{tabular}{cccc}
\hline No. & Jenis Kesalahan & \multicolumn{2}{c}{ Indikator-Indikator Kesalahan } \\
\hline 1. & Kesalahan Konsep & $\begin{array}{l}\text { - Kesalahan dalam menentukan nilai fungsi } \\
\text { trigonometri sudut tidak lancip. }\end{array}$ \\
& & $\begin{array}{l}\text { Kesalahan dalam menentukan tanda dari nilai fungsi } \\
\text { trigonometri pada masing-masing kuadran. }\end{array}$ \\
2. Kesalahan Hitung & $\begin{array}{l}\text { Kesalahan dalam menentukan hasil operasi hitung. } \\
\text { Kesalahan mengidentifikasi informasi yang diketahui } \\
\text { 3. Kesalahan Fakta }\end{array}$ & \\
\hline
\end{tabular}

Alasan peneliti menglasifikasikan kesalahan mahasiswa berdasarkan kesalahan konsep, kesalahan hitung, dan kesalahan fakta dikarenakan dalam materi nilai fungsi trigonometri sudut tidak lancip memuat konsep sudut referensi, definisi fungsi trigonometri segitiga, nilai fungsi trigonometri sudut lancip, dan tanda dari nilai fungsi trigonometri pada masing-masing kuadran. Jika mahasiswa salah dalam memahami konsep-konsep tersebut, maka mahasiswa mengalami kesalahan konsep. Selanjutnya jika mahasiswa salah dalam menentukan hasil perhitungan, maka mahasiswa mengalami kesalahan hitung. Jika mahasiswa salah dalam mengidentifikasi informasi yang ada dalam soal atau salah memahami makna simbol, maka mahasiswa mengalami kesalahan fakta.

Analisis data yang berupa transkrip hasil wawancara dilakukan dengan pengodean dengan tujuan untuk mengetahui faktor-faktor penyebab kesalahan yang dilakukan oleh mahasiswa. Pengkodean dilakukan berdasarkan kata-kata yang menunjukkan penyebab munculnya kesalahan. Melalui pengkodean ini diharapkan dapat terungkap faktorfaktor penyebab kesalahan yang dilakukan oleh mahasiswa dalam menyelesaikan masalah fungsi trigonometri sudut tidak lancip.
Validasi hasil temuan ini yang berupa kesalahan mahasiswa dalam menyelesaikan masalah fungsi trigonometri sudut tidak lancip dilakukan dengan cara bertanya kembali kepada subjek melalui wawancara, yaitu apakah mereka setuju dengan temuan ini dan meminta subjek untuk mengecek kembali keakuratan temuan ini (Creswell, 2012). Ketujuh subjek mengatakan bahwa hasil temuan ini telah akurat dan sesuai dengan kesalahan yang mereka lakukan. Jadi dapat dikatakan bahwa hasil penelitian ini telah valid sesuai kesalahan yang dilakukan oleh mahasiswa.

\section{HASIL DAN PEMBAHASAN}

Hasil penelitian menunjukkan bahwa dari 82 mahasiswa yang menyelesaikan masalah fungsi trigonometri sudut tidak lancip diperoleh 38 mahasiswa mengalami kesalahan. Dari 38 mahasiswa tersebut diperoleh klasifikasi kesalahan mahasiswa dalam menyelesaikan masalah fungsi trigonometri sudut tidak lancip yang dapat dilihat dalam Tabel 2 .

Pada Tabel 2 dapat dilihat bahwa dari 38 mahasiswa yang mengalami kesalahan dalam menyelesaikan masalah fungsi trigonometri sudut tidak lancip diperoleh: $53 \%$ mengalami kesalahan konsep, $31 \%$ mengalami kesalahan hitung, dan $16 \%$ mengalami kesalahan fakta. 
DOI: https://doi.org/10.24127/ajpm.v10i2.3458

Tabel 2. Hasil klasifikasi kesalahan mahasiswa dalam menyelesaikan masalah fungsi trigonometri sudut tidak lancip

\begin{tabular}{|c|c|c|c|}
\hline $\begin{array}{c}\text { Jenis } \\
\text { Kesalahan }\end{array}$ & $\begin{array}{l}\text { Indikator-Indikator } \\
\text { Kesalahan }\end{array}$ & $\begin{array}{l}\text { Kesalahan dalam Menyelesaikan Masalah } \\
\text { Trigonometri Sudut Tidak Lancip }\end{array}$ & $\begin{array}{c}\text { Banyak } \\
\text { Mahasiswa }\end{array}$ \\
\hline \multirow[t]{5}{*}{$\begin{array}{l}\text { Kesalahan } \\
\text { konsep }\end{array}$} & $\begin{array}{l}\text { Kesalahan menentukan } \\
\text { nilai fungsi } \\
\text { trigonometri sudut }\end{array}$ & $\begin{array}{l}\text { Kesalahan dalam menentukan nilai fungsi } \\
\text { trigonometri sudut tidak lancip yang lebih } \\
\text { dari tiga fungsi trigonometri }\end{array}$ & 5 \\
\hline & tidak lancip & $\begin{array}{l}\text { Kesalahan menentukan nilai csc dan sec } \\
\text { untuk sudut tidak lancip. }\end{array}$ & 1 \\
\hline & & $\begin{array}{l}\text { Kesalahan menentukan nilai csc untuk sudut } \\
\text { tidak lancip. }\end{array}$ & 5 \\
\hline & & $\begin{array}{l}\text { Kesalahan menentukan nilai cot untuk sudut } \\
\text { tidak lancip. }\end{array}$ & 5 \\
\hline & $\begin{array}{l}\text { Kesalahan menentukan } \\
\text { tanda dari nilai fungsi } \\
\text { trigonometri }\end{array}$ & $\begin{array}{l}\text { Tidak memperhatikan tanda pada kuadran di } \\
\text { masing-masing sudut tidak lancip. }\end{array}$ & 4 \\
\hline \multirow[t]{4}{*}{$\begin{array}{l}\text { Kesalahan } \\
\text { Hitung }\end{array}$} & $\begin{array}{l}\text { Kesalahan dalam } \\
\text { menentukan hasil } \\
\text { operasi hitung }\end{array}$ & $\begin{array}{l}\text { Kesalahan menghitung hasil penjumlahan dan } \\
\text { pengurangan bilangan bulat dengan bilangan } \\
\text { pecahan. }\end{array}$ & 2 \\
\hline & & $\begin{array}{l}\text { Kesalahan menghitung hasil pangkat dua dari } \\
\text { bilangan yang memuat bentuk pecahan dan } \\
\text { bentuk akar. }\end{array}$ & 4 \\
\hline & & $\begin{array}{l}\text { Kesalahan menghitung hasil perkalian } \\
\text { bilangan bulat dengan bilangan pecahan. }\end{array}$ & 3 \\
\hline & & $\begin{array}{l}\text { Kesalahan menghitung hasil pembagian } \\
\text { bilangan pecahan. }\end{array}$ & 3 \\
\hline \multirow{3}{*}{$\begin{array}{l}\text { Kesalahan } \\
\text { Fakta }\end{array}$} & Kesalahan mengidenti- & Kesalahan menulis soal kembali. & 5 \\
\hline & $\begin{array}{l}\text { fikasi informasi yang } \\
\text { ada dalam soal. }\end{array}$ & $\begin{array}{l}\text { Kesalahan dalam memperhatikan soal yang } \\
\text { diketahui. }\end{array}$ & 1 \\
\hline & & Total & 38 \\
\hline
\end{tabular}

Hasil pada Tabel 2 memiliki arti bahwa mahasiswa banyak mengalami kesalahan konsep dalam menyelesaikan masalah fungsi trigonometri sudut tidak lancip. Selanjutnya dari masing-masing jenis kesalahan diambil 2 mahasiswa sebagai subjek penelitian (kecuali untuk kesalahan konsep diambil 3 mahasiswa), sehingga diperoleh subjek penelitian ini sebanyak 7 mahasiswa. Selanjutnya, ketujuh subjek penelitian ini dianalisis lebih lanjut mengenai hasil pekerjaan dan dilakukan wawancara untuk mengetahui faktor-faktor penyebab munculnya kesalahan tersebut. Hasil analisis jawaban dan hasil wawancara dari ketujuh subjek dipaparkan berikut ini.

\section{Kesalahan Konsep}

Kesalahan konsep yang pertama adalah kesalahan dalam menentukan nilai fungsi trigonometri sudut tidak lancip. Terdapat 16 mahasiswa yang mengalami kesalahan ini. Dari 16 mahasiswa ini dipilih 2 mahasiswa sebagai subjek pertama (S1) dari mahasiswa yang mengalami kesalahan dalam menentukan nilai fungsi trigonometri yang lebih dari tiga fungsi trigonometri. Selanjutnya, subjek kedua (S2) dipilih dari mahaiswa yang mengalami kesalahan dalam menentukan tiga fungsi trigonometri sudut tidak lancip. Hasil pekerjaan subjek pertama (S1) ini dapat dilihat dalam Gambar 2, sedangkan hasil pekerjaan subjek kedua (S2) ini dapat dilihat dalam Gambar 3. 
DOI: https://doi.org/10.24127/ajpm.v10i2.3458

$$
\text { a) } \begin{aligned}
& 3 \sin ^{2} 120^{\circ}-2 \cos ^{2} 120^{\circ}-\cos ^{2} 180^{\circ}-\csc ^{2} 135^{\circ}+\sec ^{2} 120^{\circ} \\
= & 3\left(\frac{1}{2}\right)^{2}-2(-1)^{2}-(-1)^{2}-(1)^{2}+(1)^{2} \\
= & 3 \cdot \frac{1}{4}-2-1-1+1 \\
= & \frac{3}{4}-1 \\
= & -\frac{1}{4} \\
\text { b) } \csc ^{2} 135^{\circ}+\sec ^{2} 150^{\circ}-\cot ^{2} 210^{\circ} & =\left(\frac{2}{3} \sqrt{3}\right)^{2}+\left(\frac{2}{3} \sqrt{3}\right)^{2}-(\sqrt{3})^{2} \\
& =\frac{4}{3}+\frac{4}{3}-3 \\
& =\frac{4+4-9}{3}=-\frac{1}{3}
\end{aligned}
$$

Gambar 2. Kesalahan menentukan nilai fungsi trigonometri

Dari Gambar 2 dapat dilihat bahwa subjek mengalami kesalahan dalam menentukan nilai fungsi trigonometri, yaitu $\sin 120^{\circ}=\frac{1}{2}$, $\cos 120^{\circ}=-1, \quad \csc 135^{\circ}=\frac{2}{3} \sqrt{3}$, $\sec 120^{\circ}=1, \quad$ dan $\quad \sec 150^{\circ}=\frac{2}{3} \sqrt{3}$. Sedangkan jawaban yang benar adalah $\sin 120^{\circ}=\frac{1}{2} \sqrt{3}, \quad \cos 120^{\circ}=-\frac{1}{2}$, $\csc 135^{\circ}=\sqrt{2}, \quad \sec 120^{\circ}=-2, \quad$ dan $\sec 150^{\circ}=-\frac{2}{3} \sqrt{3}$. Faktor penyebab kesalahan ini dapat diketahui dari cuplikan transkrip wawancara berikut.

$\begin{array}{ll}P \quad: \quad & \text { Jelaskan cara Anda menyelesaikan } \\ & \text { soal a? } \\ & \text {.. Sin } 120 \text { derajat saya tulis } \\ & \text { setengah karena kesalahan saya } \\ & \text { yaitu sin } 90 \text { ditambah } 30, \text { yaitu sin } \\ & \text { 30. Kemudian }-2 \text { cos kuadrat } 120 \\ & \text { saya tulis cos } 90 \text { ditambah cos } 30, \\ & \text { saya tulis di sana }-1 . \text { Kemudian cos } \\ & \text { 180 itu nilainya }-1 . \text { Cosecan } 135, \\ & \text { saya mengerjakannya cosecant } 90 \\ & \text { ditambah } 45 \text { yaitu cosecant } 45 \\ & \text { yang seharusnya akar dua saya } \\ & \text { tulis disana 1. Kemudian secan }\end{array}$

\section{kuadrat 120, nilai secant itu dari 1 per cos 120 derajat, yaitu 1 per cos 120 saya tulis lagi 1.}

Dari cuplikan transkrip hasil wawancara dapat diketahui bahwa kesalahan subjek dalam menentukan nilai $\sin 120^{\circ}$ dengan cara mengubah menjadi $\sin (90+30)^{0}=\sin 30^{\circ}=\frac{1}{2}$. Subjek juga mengalami kesalahan menentukan nilai $\cos 120^{\circ}$, yaitu mengubah menjadi $\cos 120^{\circ}=$ $\cos (90+30)^{0}=\cos 30$. Begitu juga subjek juga mengalami kesalahan dalam menentukan nilai cosecant. Berdasarkan cuplikan transkrip wawancara diperoleh bahwa faktor yang menyebabkan subjek mengalami kesalahan dalam menentukan nilai fungsi trigonometri adalah kesalahpahaman dalam mencari sudut referensi dari sudut tidak lancip dan hanya menghafal nilai dari sudut tidak lancip. Oleh karena itu penting untuk memberikan pemahaman tentang sudut referensi.

$$
\text { a). } \begin{aligned}
& 3 \sin ^{2} 120^{\circ}-2 \cos ^{2} 120^{\circ}-\cos ^{2} 180^{\circ}-\csc ^{2} 135^{6}+\sec ^{2} 120^{\circ} \\
= & 3 \cdot\left(\frac{1}{2} \sqrt{3}\right)^{2}-2(1 / 2)^{2}-(-1)^{2}-\left(-\frac{1}{2} \sqrt{2}\right)^{2}+(-1)^{2} \\
= & 9 / 4-2 / 4-1-2 / 4+1 \\
= & 5 / 4
\end{aligned}
$$

Gambar 3. Kesalahan menentukan nilai fungsi trigonometri 
DOI: https://doi.org/10.24127/ajpm.v10i2.3458

Dari Gambar 3 dapat dilihat bahwa subjek melakukan kesalahan dalam menentukan nilai fungsi trigonometri, yaitu $\cos 120^{\circ}=\frac{1}{2}$, $\csc 135^{\circ}=-\frac{1}{2} \sqrt{2}, \quad$ dan $\quad \sec 120^{\circ}=$ -1 . Sedangkan jawaban yang benar adalah $\cos 120^{\circ}=-\frac{1}{2}, \csc 135^{\circ}=\sqrt{2}$, dan $\sec 120^{\circ}=-2$. Faktor penyebab kesalahan subjek dapat diketahui dari cuplikan transkrip wawancara berikut.

$\begin{array}{ll}P \quad: & \text { Jelaskan cara Anda menyelesaikan } \\ & \text { soal a? } \\ & \text {... Nah disini saya memasukkan } \\ & \text { nilai dari fungsi trigonometrinya } \\ & \text { terlebih dahulu, sehingga menjadi } 3 \\ & \text { kali setengah akar tiga kuadrat } \\ & \text { dikurangi } 2 \text { kali setengah kuadrat, } \\ & \text { dikurangi negatif satu kuadrat } \\ \text { dikurangi negatif setengah akar } \\ \text { dua kuadrat, ditambah -1 kuadrat. } \\ \text { Setelah itu, nilai yang ada dalam } \\ \text { tanda kurung saya kuadratkan } \\ \text { terlebih dahulu. Lalu hasil dari } \\ \text { nilai yang telah saya kuadratkan, } \\ \text { saya kalikan dengan koefisien dari } \\ \text { setiap nilai fungsi trigonometrinya, } \\ \text { sehingga setiap nilai dari fungsi } \\ \text { trigonometri tersebut adalah 9/4 - } \\ \text { 2/4 - 1 - 2/4 +1, kemudian saja } \\ \text { jumlahkan, sehingga mendapatkan } \\ \text { nilai akhir 5/4. }\end{array}$

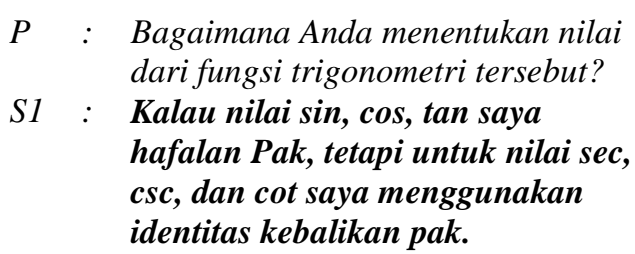
dari fungsi trigonometri tersebut?

S1 : Kalau nilai sin, cos, tan saya hafalan Pak, tetapi untuk nilai sec, csc, dan cot saya menggunakan identitas kebalikan pak.

Dari cuplikan transkrip wawancara dapat diketahui bahwa subjek menyelesaikan masalah nilai fungsi trigonometri trigonometri sudut tidak lancip dengan menggunakan hafalan dan identitas kebalikan. Akan tetapi subjek mengalami kesalahan saat hanya menggunakan hafalan. Ini artinya faktor penyebab subjek mengalami kesalahan dalam menentukan nilai fungsi trigonometri adalah pemikiran intuitif yang hanya berdasarkan hafalan.

Kesalahan konsep yang kedua adalah tidak memperhatikan letak kuadran dalam menyelesaikan masalah fungsi trigonometri sudut tidak lancip. Terdapat 4 mahasiswa yang mengalami kesalahan ini. Dari 4 mahasiswa tersebut dipilih satu subjek sebagai subjek ketiga (S3) dalam penelitian ini. Hasil pekerjaan subjek ketiga dapat dilihat dalam Gambar 4.

$$
\begin{aligned}
& \csc ^{2} 135^{\circ}+\sec ^{2} 150^{\circ}-\cot ^{2} 210^{\circ} \\
& =(\sqrt{2})^{2}+\left(\frac{2}{3} \sqrt{3}\right)^{2}-(\sqrt{3})^{2} \\
& =2+4 / 3-3=11
\end{aligned}
$$

Gambar 4. Kesalahan menentukan tanda dari nilai fungsi trigonometri

Dari Gambar 4 dapat dilihat bahwa subjek salah dalam menentukan nilai dari $\sec 150^{\circ}=\frac{2}{3} \sqrt{3}$, dimana kesalahan subjek adalah tidak memberi tanda negatif dari hasil $\sec 150^{\circ}=$ $-\frac{2}{3} \sqrt{3}$. Faktor penyebab kesalahan subjek dapat diketahui dari cuplikan transkrip hasil wawancara berikut.
$P \quad$ : Coba jelaskan bagaimana cara yang Anda gunakan?

S3 : Cosecan kuadrat 135 itu kan akar 2 kuadrat, lalu secan kuadrat 150, secan 150 itu 2/3 akar 3, jadi secan kuadrat 150 yaitu 2/3 akar 3 kuadrat, lalu cotangen kuadrat 210. Cotengen kuadrat 210 itu sendiri yaitu akar 3, jadi cotangen kuadrat 210 yaitu akar 3 kuadrat. 
Dari cuplikan transkrip hasil wawancara dapat diketahui bahwa subjek menentukan nilai fungsi trigonometri sudut tidak lancip hanya berdasarkan hafalan. Ini artinya faktor penyebab subjek mengalami kesalahan dalam menentukan tanda dari nilai fungsi trigonometri sudut tidak lancip disebabkan hafalan.

\section{Kesalahan Hitung}

Kesalahan kedua yang dilakukan oleh mahasiswa dalam menyelesaikan

$$
\text { b) } \begin{aligned}
& \csc ^{2} 135^{\circ}+\sec ^{2} 150^{\circ}-\cot ^{2} 210^{\circ} \\
= & (\sqrt{2})^{2}+\left(-\frac{2}{3} \sqrt{3}\right)^{2}-(\sqrt{3})^{2} \\
= & 4+4-3 \\
= & 5
\end{aligned}
$$

(a) Kesalahan hasil pangkat dua

$$
\text { 4. a. } \begin{aligned}
& 3 \sin ^{2} 120^{\circ}-2 \cos ^{2} 120^{\circ} \\
& 3\left(\frac{1}{2} \sqrt{3}\right)^{2}-2\left(-\frac{1}{2}\right)^{2} \\
& 3\left(\frac{1}{4} \cdot 3\right)-2\left(\frac{1}{4}\right) \\
& 9 \frac{1}{4}-\frac{1}{2}
\end{aligned}
$$

(b) Kesalahan hasil perkalian masalah fungsi trigonometri sudut tidak lancip adalah kesalahan hitung. Ada 4 jenis kesalahan hitung yang dilakukan oleh mahasiswa saat menyelesaikan masalah fungsi trigonometri sudut tidak lancip, yaitu: kesalahan hasil pangkat dua (lihat Gambar 5a), kesalahan hasil perkalian bilangan bulat dengan pecahan (lihat Gambar 5b), kesalahan pembagian pecahan (lihat Gambar 5c), dan kesalahan penjumlahan dan pengurangan bilangan bulat dengan bilangan pecahan (lihat Gambar 5d).

$$
\begin{aligned}
& =\frac{1}{1 / 2}+\frac{1}{3 / 4}-\frac{3 / 4}{1 / 4} \\
& =2+\frac{4}{3}-1=\frac{6+4-3}{3}=\frac{7}{3}=2 \frac{1}{3}
\end{aligned}
$$

(c) Kesalahan hasil pembagian

$$
\begin{aligned}
& \csc ^{2} 135^{\circ}+\sec ^{2} 150^{\circ}-\cot ^{2} 210^{\circ} \\
& =(\sqrt{2})^{2}+\left(\frac{2}{3} \sqrt{3}\right)^{2}-(\sqrt{3})^{2} \\
& =2+4 / 3-3 \\
& =1
\end{aligned}
$$

(e) Kesalahan hasil penjumlahan

Gambar 5. Kesalahan hitung dalam menyelesaikan masalah fungsi trigonometri

Dari Gambar 5(a) dapat dilihat bahwa kesalahan hitung yang pertama adalah menentukan hasil dari pangkat dua, yaitu $\left(-\frac{2}{3} \sqrt{3}\right)^{2}=4$, jawaban yang benar adalah $\left(-\frac{2}{3} \sqrt{3}\right)^{2}=\frac{4}{3}$. Kesalahan hitung yang kedua (lihat Gambar 5b), yaitu $3\left(\frac{1}{4} \cdot 3\right)=9 \frac{1}{4}$, dimana jawaban yang benar adalah $3\left(\frac{1}{4} \cdot 3\right)=\frac{9}{4}$. Kesalahan hitung yang ketiga (lihat Gambar 5c), yaitu $\frac{3}{4} \div \frac{1}{4}=1$, dimana jawaban yang benar adalah $\frac{3}{4} \div \frac{1}{4}=3$.
Kesalahan hitung yang keempat (lihat Gambar 4d), yaitu $2+\frac{4}{3}-3=1$, dimana jawaban yang benar adalah $2+\frac{4}{3}-3=\frac{1}{3}$. Dari keempat jenis kesalahan ini dipilih dua mahasiswa sebagai subjek keempat (S4) dan sebagai subjek kelima (S5) untuk dilakukan wawancara lebih lanjut dengan tujuan mengetahui faktor-faktor penyebab kesalahan. Cuplikan transkrip wawancara yang menunjukkan faktorfaktor penyebab subjek melakukan kesalahan hitung adalah berikut ini. 


$$
\begin{array}{ll}
P \quad: \quad & \text { Mengapa Anda menulis }(\sqrt{2})^{2}=4 \\
& \text { dan }\left(-\frac{2}{3} \sqrt{3}\right)^{2}=4 \\
& \text { Mohon maaf pak, saya kurang teliti } \\
& \text { dan terburu-buru dalam } \\
& \text { menyelesaikan soal tersebut, } \\
& \text { seharusnya jawabannya adalah } 2 \\
& \text { dan } 4 \text { per } 3 . \\
& \text { Mengapa Anda menulis hasil dari } \\
& 3\left(\frac{1}{4} \cdot 3\right)=9 \frac{1}{4} ? \\
\text { S5 }: \quad & \text { Itu karena } 1 \text { per } 4 \text { titik } 3 \text { kurung, } \\
& \text { dikali tiga, itu sama saja } 3 \text { per } 4 \\
& \text { dikali } 3 \text { per } 1 \text { gitu pak, jadi kan } \\
& \text { nanti hasilnya pertama itu } 3 \text { per } 4 . \\
& \text { Nah itu kan ... udah ketemu, jadi } 3 \\
& \text { dikali } 3 \text { per } 4 \text { gitu pak, kan nanti } \\
& \text { sama saja kayak } 3 \text { per } 1, \text { dikali } 3 \\
& \text { per } 4, \text { sama dengan } 9 \text { per } 4 \text {, kayak } \\
& \text { saya pecah menjadi } 9,1 \text { per } 4 \text { gitu } \\
\text { pak }
\end{array}
$$

Dari cuplikan transkrip wawancara dapat diketahui bahwa faktor penyebab subjek mengalami kesalahan dalam menentukan hasil pangkat dua adalah kurang teliti dan terburu-buru. Sedangkan faktor penyebab subjek mengalami kesalahan

$$
\text { b) } \begin{aligned}
& \csc ^{2} 135^{\circ}+\sec ^{2} 150^{\circ} \\
= & (\sqrt{2})^{2}+\left(-\frac{2}{3} \sqrt{3}\right) \\
= & 2-\frac{2}{3} \sqrt{3}
\end{aligned}
$$

(a) Kesalahan Memperhatikan Soal dalam menentukan hasil perkalian bilangan bulat dengan pecahan adalah kesalahpahaman dalam mengubah pecahan biasa menjadi pecahan campuran, dimana kesalahan subjek adalah mengubah pecahan $\frac{9}{4}$ menjadi pecahan $9 \frac{1}{4}$. Ini artinya faktor penyebab kesalahan hitung dalam menyelesaikan masalah fungsi trigonometri sudut tidak lancip yaitu kesalahpahaman dalam mengubah pecahan biasa ke bentuk pecahan campuran dan kurang teliti.

\section{Kesalahan Fakta}

Kesalahan ketiga yang dialami oleh mahasiswa semester pertama dalam menyelesaikan masalah fungsi trigonometri sudut tidak lancip adalah kesalahan fakta. Terdapat dua kesalahan fakta yang dilakukan oleh mahasiswa, yaitu kesalahan memperhatikan soal (lihat Gambar 6a) dan kesalahan menulis soal (lihat Gambar 6b).

\section{Gambar 6. Kesalahan fakta}

Dari Gambar 6(a) dapat dilihat bahwa kesalahan subjek adalah tidak mengoperasikan $\left(-\frac{2}{3} \sqrt{3}\right)$ dengan pangkat dua, padahal dalam soal diketahui $\sec ^{2} 150^{\circ}$. Jadi seharusnya jawaban yang benar adalah $\sec ^{2} 150^{\circ}=$ $\left(-\frac{2}{3} \sqrt{3}\right)^{2}=\frac{4}{3}$ Dari Gambar 6(b) dapat dilihat bahwa subjek melakukan kesalahan dalam menuliskan soal, yaitu $\cot ^{2} 120^{\circ}$, dimana soal yang benar adalah $\cot ^{2} 210^{\circ}$. Akibat dari kesalahan mengidentifikasi soal dan menuliskan soal kembali, maka subjek mengalami kesalahan dalam menyelesaikan masalah fungsi trigonometri sudut tidak lancip. Dari kedua jenis kesalahan ini dipilih dua mahasiswa sebagai subjek keenam (S6) dan subjek ketujuh (S7) yang mengalami kesalahan fakta untuk dilakukan wawancara yang bertujuan mengetahui faktor-faktor penyebab 
DOI: https://doi.org/10.24127/ajpm.v10i2.3458

munculnya kesalahan. Faktor penyebab munculnya kesalahan fakta ini dapat diketahui dari cuplikan transkrip wawancara berikut.

$$
\begin{aligned}
& P \quad \text { : Coba jelaskan cara Anda } \\
& \text { menjawab soal tersebut? } \\
& \text { S6 : ... setelah itu akar } 2 \text { kuadrat itu } \\
& P \quad \text { : Coba jelaskan cara Anda? } \\
& \text { S7 : Ternyata setelah saya cek kembali }
\end{aligned}
$$

Dari cuplikan transkrip hasil wawancara dapat diketahui bahwa faktor penyebab subjek mengalami kesalahan fakta dalam menyelesaikan masalah adalah kurang teliti dan tidak

\begin{tabular}{|c|c|c|}
\hline $\begin{array}{c}\text { Jenis } \\
\text { Kesalahan }\end{array}$ & Deskripsi Kesalahan & Faktor-Faktor Penyebabnya \\
\hline $\begin{array}{l}\text { Kesalahan } \\
\text { Konsep }\end{array}$ & $\begin{array}{l}\text { Kesalahan konsep dalam } \\
\text { menyelesaikan masalah fungsi } \\
\text { trigonometri sudut tidak lancip yaitu } \\
\text { kesalahan dalam menentukan nilai } \\
\text { fungsi trigonometri sudut tidak } \\
\text { lancip dan tidak memperhatikan } \\
\text { letak kuadran. }\end{array}$ & $\begin{array}{l}\text { Faktor-faktor penyebab dari } \\
\text { kesalahan konsep ini yaitu } \\
\text { kesalahpahaman dalam mencari } \\
\text { sudut referensi dari sudut tidak } \\
\text { lancip dan hanya menghafal } \\
\text { nilai-nilai dari fungsi } \\
\text { trigonometri tidak lancip. }\end{array}$ \\
\hline $\begin{array}{l}\text { Kesalahan } \\
\text { Hitung }\end{array}$ & $\begin{array}{l}\text { Kesalahan hitung dalam } \\
\text { menyelesaikan masalah fungsi } \\
\text { trigonometri sudut tidak lancip, } \\
\text { yaitu: (1) kesalahan hasil pangkat } \\
\text { dua, (2) kesalahan perkalian bilangan } \\
\text { bulat dengan pecahan, (3) kesalahan } \\
\text { pembagian bilangan pecahan, dan (4) } \\
\text { kesalahan penjumlahan dan } \\
\text { pengurangan. }\end{array}$ & $\begin{array}{l}\text { Faktor-faktor penyebab } \\
\text { kesalahan hitung ini, yaitu } \\
\text { kurang teliti dan } \\
\text { kesalahpahaman dalam } \\
\text { mengubah bilangan pecahan } \\
\text { biasa ke dalam pecahan } \\
\text { campuran. }\end{array}$ \\
\hline $\begin{array}{l}\text { Kesalahan } \\
\text { Fakta }\end{array}$ & $\begin{array}{l}\text { Kesalahan fakta dalam } \\
\text { menyelesaikan masalah fungsi } \\
\text { trigonometri sudut tidak lancip, yaitu } \\
\text { kesalahan dalam memperhatikan soal } \\
\text { dan kesalahan dalam menuliskan } \\
\text { soal kembali. }\end{array}$ & $\begin{array}{l}\text { Faktor-faktor penyebab } \\
\text { kesalahan fakta ini yaitu kurang } \\
\text { teliti dan tidak mengecek } \\
\text { kembali hasil pekerjaan dengan } \\
\text { informasi yang ada dalam soal. }\end{array}$ \\
\hline
\end{tabular}
mengecek kembali hasil pekerjaan mereka dengan informasi yang diketahui dalam soal.

Dari hasil penelitian diperoleh deskripsi kesalahan mahasiswa dalam menyelesaikan masalah fungsi trigonometri sudut tidak lancip beserta faktor-faktor penyebabnya yang dapat dilihat dalam Tabel 3.

Tabel 3. Deskripsi kesalahan mahasiswa dalam menyelesaikan masalah fungsi trigonometri sudut tidak lancip

Hasil penelitian ini secara umum berkonstribusi mengembangkan teori kesalahan dalam menyelesaikan masalah matematika dalam materi nilai fungsi trigonometri sudut tidak lancip. Hasil penelitian menunjukkan bahwa kesalahan mahasiswa semester pertama dalam menyelesaikan masalah fungsi 
trigonometri sudut tidak lancip terdiri dari kesalahan konsep, kesalahan hitung, dan kesalahan fakta. Hasil penelitian ini sesuai dengan hasil penelitian sebelumnya yang menunjukkan bahwa mahasiswa semester pertama mengalami kesalahan konsep, kesalahan hitung, dan kesalahan fakta dalam menyelesaikan masalah trigonometri (Abidin, 2012; Hidayat \& Aripin, 2020; Imelda, 2018; Jaelani, 2017). Akan tetapi hasil penelitian memperluas hasil penelitian sebelumnya dengan menjelaskan kesalahan tersebut dalam materi nilai fungsi trigonometri sudut tidak lancip.

Kesalahan pertama adalah kesalahan konsep. Hasil penelitian ini sesuai dengan hasil penelitian sebelumnya yang menunjukkan bahwa mahasiswa semester pertama mengalami kesalahan konsep dalam menyelesaikan masalah trigonometri (Abidin, 2012; Hidayat \& Aripin, 2020). Hasil penelitian ini memperluas hasil penelitian sebelumnya dengan menjelaskan kesalahan konsep dalam menyelesaikan masalah nilai fungsi trigonometri sudut tidak lancip. Kesalahan konsep ini muncul karena kesalahpahaman dalam menentukan sudut referensi dari sudut tidak lancip dan tidak memperhatikan tanda dari masing-masing fungsi trigonometri di keempat kuadran. Misalnya dalam menentukan nilai dari $\sin 120^{\circ}$, subjek mengalami kesalahpahaman dalam menentukan sudut referensi dari $120^{\circ}$ yaitu $90^{\circ}+30^{\circ}$, dimana subjek menuliskan sudut referensi dari $120^{\circ}$ adalah $30^{\circ}$. Akibatnya subjek salah dalam menentukan nilai sin $120^{\circ}$.

Kesalahan kedua adalah kesalahan hitung. Hasil penelitian ini sesuai dengan hasil penelitian sebelumnya yang menunjukkan bahwa mahasiswa semester pertama juga mengalami kesalahan hitung dalam menyelesaikan masalah trigonometri (Imelda, 2018). Hasil penelitian ini memperluas hasil penelitian sebelumnya dengan menjelaskan kesalahan hitung yang dilakukan oleh mahasiswa dalam menyelesaikan masalah fungsi trigonometri sudut tidak lancip. Kesalahan hitung ini banyak terjadi saat mahasiswa kurang teliti dalam melakukan perhitungan, terutama saat melakukan pembagian bilangan pecahan, hasil kuadrat dari bilangan akar, dan penjumlahan yang melibatkan bilangan pecahan dan bilangan bulat. Oleh karena itu, ketelitian ini penting untuk dimiliki oleh mahasiswa dalam menyelesaikan operasi hitung. Selain itu, kesalahan ini juga muncul disebabkan kesalahpahaman dalam mengubah pecahan biasa ke dalam pecahan campuran. Misalnya pecahan $\frac{9}{4}$ ditulis dalam bentuk $9 \frac{1}{4}$.

Kesalahan ketiga adalah kesalahan fakta. Hasil penelitian ini sesuai dengan hasil penelitian sebelumnya yang menunjukkan bahwa mahasiswa juga mengalami kesalahan fakta dalam menyelesaikan masalah trigonometri (Hidayat \& Aripin, 2020; Tuna, 2013). Hasil penelitian ini memperluas hasil penelitian sebelumnya dengan menjelaskan kesalahan fakta mahasiswa saat menyelesaikan masalah fungsi trigonometri sudut tidak lancip. Kesalahan fakta ini terjadi karena mahasiswa tidak mengecek kesesuaian jawaban maupun soal yang ditulisnya dengan soal yang diketahui. Akibatnya mahasiswa mengalami kesalahan dalam menyelesaikan masalah fungsi trigonometri sudut tidak lancip.

Hasil penelitian ini juga berimplikasi pada pembelajaran nilai fungsi trigonometri sudut tidak lancip yang bertujuan untuk mengurangi 
kesalahan-kesalahan mahasiswa dalam menyelesaikan masalah fungsi trigonometri sudut tidak lancip. Implikasi yang pertama adalah untuk mengurangi kesalahan konsep dilakukan dengan membelajarkan konsep sudut referensi dan konsep kuadran seperti yang telah dijelaskan dalam pendahuluan. Berbagai peneliti merekomendasikan untuk menekankan pada pemahaman konsep dalam melakukan pembelajaran matematika (Nabie et al., 2018; Setiawan, 2019; Setiawan \& Mustangin, 2020a, 2020b; Setiawan \& Syaifuddin, 2020).

Implikasi yang kedua adalah untuk mengurangi kesalahan hitung dilakukan dengan meminta mahasiswa untuk mengecek kembali proses maupun hasil dari operasi hitung yang dilakukannya. Terutama saat menentukan hasil kuadrat dari bilangan akar, hasil pembagian bilangan pecahan, dan hasil penjumlahan bilangan bulat dengan bilangan pecahan. Selain itu juga harus lebih teliti dalam mengubah pecahan biasa ke dalam bentuk pecahan campuran. Hasil penelitian menunjukkan bahwa tanpa ketelitian akan mengakibatkan pendekatan pemecahan masalah tidak efisien atau terjadi kesalahan dalam menghitung (Byers, 2009). Bahkan hasil penelitian juga menunjukkan bahwa dengan meliti kembali proses maupun hasil jawaban yang diperoleh, maka seseorang dapat memperbaiki kesalahan, sehingga memperoleh jawaban yang benar (Setiawan, 2020d, 2020e; Setiawan et al., 2020)

Implikasi yang ketiga adalah untuk mengurangi kesalahan fakta dilakukan dengan menekankan kepada mahasiswa untuk memperhatikan informasi yang ada dalam soal secara menyeluruh, agar tidak terjadi kesalahan dalam menuliskan soal. Hasil penelitian menunjukkan bahwa perhatian yang tidak menyeluruh terhadap informasi yang ada dalam soal dapat mengakibatkan kesalahan penyelesaian masalah (Setiawan, 2020b, 2020a). Oleh karena itu penting untuk memeriksa kembali antara kesesuaian jawaban dengan soal yang diketahui, agar tidak terjadi kesalahan fakta.

\section{KESIMPULAN DAN SARAN}

Dari hasil penelitian dapat disimpulkan bahwa kesalahan mahasiswa dalam menyelesaikan masalah fungsi trigonometri sudut tidak lancip terdiri dari kesalahan konsep, kesalahan hitung, dan kesalahan fakta. Kesalahan-kesalahan tersebut muncul dikarenakan kesalahpahaman terhadap konsep sudut referensi, tidak memperhatikan kuadran, kurang teliti dalam melakukan perhitungan, kesalahpahaman terhadap operasi hitung, dan tidak mengecek kembali jawaban yang diberikan dengan soal yang diketahui.

Meskipun penelitian ini hanya terbatas pada masalah fungsi trigonometri sudut tidak lancip, akan tetapi hasil penelitian ini berkonstribusi dalam mengembangkan teori kesalahan pada materi nilai fungsi trigonometri sudut tidak lancip. Penelitian selanjutnya dapat menganalisis kesalahan-kesalahan mahasiswa dalam menyelesaikan masalah fungsi trigonometri sudut lebih dari $360^{\circ}$ maupun sudut negatif. Karena hasil penelitian ini akan bermanfaat dalam memberikan wawasan mengenai kesalahpahaman mahasiswa yang selanjutnya dapat digunakan untuk memperbaiki pembelajaran pada materi fungsi trigonometri sudut lebih dari $360^{\circ}$ dan sudut negatif.

Saran lebih lanjut kepada para pendidik adalah untuk menghindari 
kesalahan konsep, kesalahan hitung, dan kesalahan fakta dalam membelajarkan materi fungsi trigonometri sudut tidak lancip dilakukan dengan membelajarkan konsep sudut referensi dan konsep fungsi trigonometri di masing-masing kuadran. Kemudian juga meminta mahasiswa untuk meneliti kembali proses maupun hasil operasi hitung, serta mengecek kembali kesesuaian jawaban dengan soal yang diketahui. Dengan demikian diharapkan kesalahan mahasiswa dapat dikurangi.

\section{DAFTAR PUSTAKA}

Abidin, Z. (2012). Analisis Kesalahan Mahasiswa Prodi Pendidikan Matematika Fakultas Tarbiyah IAIN AR-Raniry dalam Mata Kuliah Trigonometri dan Kalkulus 1. Jurnal Ilmiah DIDAKTIKA, 13(1), 183-196.

Byers, T. (2009). The Basic Intervention Mathematics Program for at-risk Students. Australian Mathematics Teacher, 65(1), 6-11.

Creswell, J. W. (2012). Educational Research Planning, Conducting and Evaluating Quantitative and Qualitative Research (Fourth). Pearson Education, Inc.

Downing, D. (2009). Dictionary of Mathematics Terms. In Barron's Educational Series, Inc. (Third Edit). Barron's Educational Series, Inc.

https://doi.org/10.2307/3614426

Guce, I. K. (2017). Mathematical Writing Errors in Expository Writings of College Mathematics Students. International Journal of Evaluation and Research in Education (IJERE), 6(3), 233. https://doi.org/10.11591/ijere.v6i3. 8549

Herholdt, R., \& Sapire, I. (2014). An error analysis in the early grades mathematics - a learning opportunity? South African Journal of Childhood Education, 4(1), 19. https://doi.org/10.4102/sajce.v4i1.4 6

Hidayat, W., \& Aripin, U. (2020). Identifikasi Kesalahan Jawaban Mahasiswa Pada Mata Kuliah Trigonometri Berdasarkan Dimensi Pengetahuan Krathwohl. Jurnal Nasional Pendidikan Matematika, 4(1), 142-153.

Imelda. (2018). Analisis Kesulitan Mahasiswa dalam Menyelesaikan Soal Pemecahan Masalah Pada Mata Kuliah Aljabar dan Trigonometri. Journal of Mathematics Education and Science, 4(1), 49-56.

Jaelani, A. (2017). Kesalahan jawaban tes trigonometri mahasiswa pendidikan matematika semester pertama. Journal of Mathematics Education, 3(2), 1-13.

Lial, M. L., Hornsby, J., Schneider, D. I., \& Daniels, C. J. (2016). Trigonometry (11th ed.). Pearson.

Marpa, E. P. (2019). Common Errors in Algebraic Expressions: A Quantitative-Qualitative Analysis. International Journal on Social and Education Sciences, 1(2), 6372.

https://doi.org/10.46328/ijonses.11 Murtiyasa, B., \& Wulandari, V. (2020). Analisis Kesalahan Siswa Materi Bilangan Pecahan Berdasarkan Teori Newman. AKSIOMA: Jurnal Program Studi Pendidikan Matematika, 9(3), 713-726. https://doi.org/10.24127/ajpm.v9i3. 2795

Nabie, M. J., Akayuure, P., IbrahimBariham, U. A., \& Sofo, S. (2018). Trigonometric concepts: Preservice teachers' perceptions and 
DOI: https://doi.org/10.24127/ajpm.v10i2.3458

knowledge. Journal on Mathematics Education, 9(2), 169182.

https://doi.org/10.22342/jme.9.2.52 61.169-182

Nejad, M. J. (2016). Undergraduate Students' Perception of Transformation of Sinusoidal Functions. In M. B. Wood, E. E. Turner, M. Civil, \& J. A. Eli (Eds.), Proceedings of the 38th annual meeting of the North American Chapter of the International Group for the Psychology of Mathematics Education (pp. 589-596). The University of Arizona.

Setiawan, Y. E. (2020a). Analisis Kemampuan Siswa dalam Pembuktian Kesebangunan Dua Segitiga. Al-Khwarizmi: Jurnal Pendidikan Matematika Dan Ilmu Pengetahuan Alam, 8(1), 23-38. https://doi.org/http://dx.doi.org/10. 24256/jpmipa.v8i1.800

Setiawan, Y. E. (2020b). Analisis Kesalahan Siswa dalam Menggeneralisasi Pola Linier. Jurnal Nasional Pendidikan Matematika, 4(2), 180-194. https://doi.org/http://dx.doi.org/10. 33603/jnpm.v4i2.3386

Setiawan, Y. E. (2020c). Analisis Kesalahan Siswa dalam Menilai Kebenaran Suatu Pernyataan. Jurnal Didaktik Matematika, 7(1), 13-31.

https://doi.org/10.24815/jdm.v7i1. 14495

Setiawan, Y. E. (2020d). Proses Berpikir Siswa dalam Memperbaiki Kesalahan Generalisasi Pola Linier. Mosharafa: Jurnal Pendidikan Matematika, 9(3), 371-382. https://doi.org/https://doi.org/10.31 980/mosharafa.v9i3.751
Setiawan, Y. E. (2020e). The Thinking Process of Students Using Trial and Error Strategies in Generalizing Linear Patterns. Numerical: Jurnal Matematika Dan Pendidikan Matematika, 4(1), $1-12$.

https://doi.org/https://doi.org/10.25 217/numerical.v4i1.839

Setiawan, Y. E. (2021a). Analisis Kesalahan Mahasiswa Semester Pertama dalam Menentukan Nilai Fungsi Trigonometri Sudut Istimewa. Supremum Journal of Mathematics Education, 5(1), 110121.

https://doi.org/https://doi.org/10.35 706/sjme.v5i1.4531

Setiawan, Y. E. (2021b). Analisis Kesalahan Mahasiswa Semester Pertama dalam Menentukan Nilai Fungsi Trigonometri Sudut Kuadran. Jurnal Cendekia: Jurnal Pendidikan Matematika, 5(1), 321-334.

https://doi.org/https://doi.org/10.31 004/cendekia.v5i1.413

Setiawan, Y. E., \& Mustangin. (2020a). Kepraktisan Model Pembelajaran IDEA (Issue, Discussion, Establish, and Apply) dalam Pembelajaran Matematika. Aksioma: Jurnal Program Studi Pendidikan Matematika, 9(3), 776-788.

https://doi.org/https://doi.org/10.24 127/ajpm.v9i3.2917

Setiawan, Y. E., \& Mustangin. (2020b). Validitas Model Pembelajaran IDEA ( Issue, Discussion, Establish, and Apply) untuk Meningkatkan Pemahaman Konsep. Jurnal Penelitian Pendidikan Dan Pengajaran Matematika, 6(1), 53-60. https://doi.org/https://doi.org/10.37 058/jp3m.v6i1.1432 
DOI: https://doi.org/10.24127/ajpm.v10i2.3458

Setiawan, Y. E., Purwanto, Parta, I. N., \& Sisworo. (2020). Generalization Strategy of Linear Patterns From Field-Dependent Cognitive Style. Journal on Mathematics Education, 11(1), 77-94. https://doi.org/http://doi.org/10.223 42/jme.11.1.9134.77-94

Setiawan, Y. E., \& Syaifuddin. (2020). Peningkatan Kompetensi Profesionalitas Guru Melalui Pelatihan Desain Pembelajaran Peta Konsep. Jurnal Pengabdian Kepada Masyarakat, 26(3), 148153.

https://doi.org/http://dx.doi.org/10. 24114/jpkm.v26i3.16377

Siregar, H. M. (2019). Analisis Kesalahan Siswa dalam Menyelesaikan Soal Tes Kemampuan Berpikir Kreatif Matematis Materi Lingkaran. Aksioma: Jurnal Program Studi Pendidikan Matematika, 8(3), 497-507.

https://doi.org/https://doi.org/10.24 127/ajpm.v8i3.2379

Tuna, A. (2013). A Conceptual Analysis of the Knowledge of Prospective Mathematics Teachers about Degree and Radian. Word Journal of Education, 3(4), 1-9. https://doi.org/10.5430/wje.v3n4p1 